\title{
THE IMPLEMENTATION OF SERIES PICTURE TOWARDS STUDENTS' SPEAKING ABILITY AT THE SECOND SEMESTER OF THE TENTH CLASS AT MA. AL-HIKMAH BANDAR LAMPUNG IN 2010/2011
}

\author{
Syafrizal \\ Bambang Suwarno \\ STKIP PGRI Bandar Lampung \\ Chairil Anwar Street, 79 Durian Payung, Tj. Karung, Lampung \\ Email : Syafrizalichan@gmail.com
}

\begin{abstract}
A series picture is a sequence of picture dealing with one subject. It may tell a story, present an event, describe a scene, reveal a person, or show how to do something. From the previous studies, series picture has been demonstrated as practical teaching and learning media for students at all grade levels. This method has been identified by researchers as an excellent media for increasing vocabulary and improving writing competence. However, the use of series picture as media for speaking has been relatively unexplored. The objective of this study is to investigate the influence of series picture as media to improve students' speaking ability. The research design of this study was preexperimental design. The population was the tenth grade students of MA Al-Hikmah Way Halim Bandar Lampung in the academic year of 2010/2011 and samples consisted of 32 students. The data was collected via test, observation and interview. In analyzing the data, $t_{\text {test }}$ formula was used, it was found that $t_{\text {ratio }}$ is 3.45 and $t_{\text {table }}$ for $\alpha=0.01$ the $t_{\text {table }}$ is 2.46 and for $\alpha=0.05$ the $t_{\text {table }}$ is 1.70 it meant that $t$ ratio was higher than $t$ table. The finding showed positive feedback received from the subject on the use series picture for their speaking ability. Based on the result of this study, it can be concluded that series picture as media is very effective to improve students' speaking ability.
\end{abstract}

Keywords: Series Pictures, Speaking Ability, Language Learning, Entertainment Education.

Abstract: Gambar berseri adalah sebuah rangkaian gambar yang berhubungan dengan satu subyek. Gambar tersebut bisa saja tentang sebuah cerita, sebuah peristiwa, menggambarkan adegan, menjelaskan seseorang ataupun menunjukkan bagaimana melakukan sesuatu. Dari hasil penelitian sebelumnya, sebagai media gambar berseri telah digunakan dalam praktek belajar mengajar untuk semua tingkatan. Metode ini telah diidentifikasi oleh para peneliti sebagai media yang tepat untuk meningkatkan kosakata dan kemampuan penulisan. Namun, kegunaan gambar berseri sebagai media untuk peningkatan berbicara kurang tereksplorasi. Tujuan penelitian ini adalah untuk menginvestigasi pengaruh gambar berseri sebagai media untuk meningkatkan kemampuan speaking siswa. Disain dari penelitian ini adalah pre-eksperimen. Populasinya adalah siswa kelas 10 MA Al-Hikmah Way Halim Bandar Lampung tahun ajaran 2010/2011 dan 32 siswa sebagai sampel penelitiannya. Data diambil melalui test, observasi dan interview. Dalam menganalisis data, rumus t-test digunakan, hasilnya tratio 3.45 dan $t$-tabel dengan $\alpha=0.01$ adalah 2.46 dan untuk $\alpha=0.05 t$-table adalah 1.70 artinya t-ratio lebih besar dari t-table. Hasil tersebut menunjukkan adanya pengaruh positif yang diterima dari subyek dalam penggunaan gambar berseri pada kemampuan speaking mereka. Berdasarkan hasil penelitian ini, dapat disimpulkan bahwa 
gambar berseri sebagai media sengatlah efektif untuk meningkatkan kemampuan berbicara siswa.

\section{Kata Kunci: Gambar Berseri, Kemampuan Berbicara, Pembelajaran Bahasa, Pendidikan Yang Menghibur.}

\section{INTRODUCTION}

A country has its own language. It is different from one to another. To communicate with different languages, people need a global language. The global language is a language used by people from different nations to communicate with each other (Smith in Zacharias, 2003: 27). It will make them understand each other what they talk about, so that they can convey their message well in the conversation. One of the global languages is English. As a global language, English gives opportunity to people open their future to be better by learning it.

Learning English is learning how to communicate it well both in oral and written. Furthermore, in Indonesia, English is taught from elementary school until university level or even in kindergarten level. Learners learn English as compulsory subject from junior high school until university, as local subject in elementary and as prestigious subject in kindergarten. So, it is undeniable that English become the language "power, success and prestige" (Graddol in Zacharias, 2003: 65).

In Indonesia, teaching English emphasizes on the students' ability of the four language skills that are listening, speaking, reading and writing. These four skills should be reinforced equally which link each other as a unity. The integration of the four skills is the only plausible approach within a communicative, interactive framework (Brown, 2001: 234).

Speaking skill is the most important aspect of learning English as foreign language. It is one of skills that to be taught in junior high school. The students are required to master speaking skill, especially to express interpersonal, ideational, and textual meanings in daily use (Curriculum 2004, Depdiknas).

The standard competence of speaking skills is enable students to communicate in spoken English accurately. It is clear that English as an international language is very important. So Indonesia government has given deep attention to students to master English especially for communication.

Yet, in fact Indonesian students still get difficulties and often reluctant to speak (Mardiana at all, 2015). They are unconfident or afraid to speak and tend to keep silent in the class. Most of them still find difficulties to use appropriate vocabulary to be expressed in a conversation.

Some say that it is difficult to memorize certain words; others say that the teachers cannot translate the proper interpretation of the words (Hustchinson \& Waters, 1987: 50). Whereas, we know that to master the language especially in speaking, students cannot avoid learning the vocabulary as part of language. 
To solve this problem, the teacher can use one technique for enriching students' vocabulary ability such as semantic mapping. Semantic mapping will help the students in brainstorm and to generate new ideas.

The use of semantic mapping has been empirically demonstrated to facilitate students' success in vocabulary development. According to Hornby (1987:631) a picture can be painting, drawing, sketch, or any work art. Harmer (2001:134) stated teachers have always used picture or graphics - whether drawn, taken from books, newspaper and magazines, or photographs - to facilitate learning". English teachers tend to feel that using pictures in teaching new words makes the process enjoyable and memorable. They also feel that pictures attract pupils' attention and deepen their understanding of vocabulary.

Pictures can also help learners with abstract words, as associating the words with a concrete object make these words easier to remember. Harmer (2001:135) stated that one of the most appropriate uses for pictures is for the presenting and checking of meaning. An easy way of explaining the meaning of the word airplane, for example, is to have a picture of one".

This series picture feature makes some researchers from our and other countries interested to investigate it further for writing and reading activity. Gutierrez at all (2015) conducted the research of Using Picture Series Technique to Enhance Narrative Writing among Ninth Grade
Students at Institution Educativa Simon Araujo in Colombia. The result was found that there was a significant difference between the group which was taught through Pictures series technique and Process-based approach over the one which only received Process-based instruction. The researchers conclude that the intervention with Picture series technique improved the overall growth of writing skills, specific to the areas of Transition or logical sequence and Ideas exposure.

Then, Rosmawati (2013) had conducted the study of series picture in enhancing the first language primary students' achievement in writing paragraph. In her research entitled "Enhancing the First Language Primary Students' Achievement in Writing Paragraph by Using Pictures" she concluded that by using picture, the first Language Primary students' achievement in writing paragraph is significantly enhanced.

Along with this Andrzejczak (2005) also investigated the benefits of integrating visual art creation and the writing process entitled "From Image to Text: Using Images in the Writing Process." This study showed that the benefits of a rich visual art experience can enhance thought and writing in response to finished artwork.

Some studies of series picture also were conducted in reading activity. Chunpan (2009) investigated the extent to which the presence of pictures in text benefits low proficiency Taiwanese English foreign language (EFL) college students.

The result showed that the lowproficiency participants had significantly higher scores on their translation tasks when 
the text was presented together with the pictures, and that the accompanying pictures facilitated those low-level participants in comprehending not only the simpler but also the more difficult text.

Nurhayati (2014) investigated the effectiveness of series picture on reading comprehension of the second semester students and her research title was "Using Picture Series to Inspire Reading Comprehension for The Second Semester Students of English Department of Iain Tulungagung." She examined whether there was significant difference between students' reading competence before and after treatment.

The result was by retelling the ideas and summarizing the text using interesting media especially picture series could increase the students' motivation in reading class especially to improve their reading comprehension.

Based on the explanation above, it can be concluded that many studies of series picture have been already conducted in reading and writing activity. However, the use of series picture for speaking class has been relatively unexplored. Whereas we know that this technique can be a guideline for stimulating the students to speak. Therefore the writer decided to conduct a research entitles the implementation of series picture to enhance speaking competence.

Speaking is very important as a part of English because the students learn to be good communicators. In teaching speaking, the teachers may not teach without rule. They should know about the principles inside. According to Nunan (1991: 54), here are the principles for teaching speaking that should be considered by teachers: (a) be aware of the difference between second language and foreign language learning contexts. (b) Give students practice with both fluency and accuracy. (c) Provide opportunities for students to talk by using group work or pair work, and limiting teacher talk. (d) Plan speaking tasks that involve negotiation for meaning. (e) Design classroom activities that involve guidance and practice in both transactional speaking.

Based on the principles above, it can be concluded that the teacher should give a chance to learners to have speaking with others. The teacher must encourage the learners to produce English by themselves but not to force them, and try to create a positive rapport with the learners by avoiding threatening atmosphere so it can help the students more relaxed and confident. The teacher has to provide opportunities for students to talk more by using group work or pair work, and limiting teacher talk. To prove whether students understand or not, the teacher can ask them to make clarification, repetition, or explanations during conversation.

In the contexts of teaching English as a foreign language, speaking may be difficult to teach and to learn if the techniques or classroom activities are not interesting and suitable for students. According to Hughes (2002), teaching speaking is not easily separated other objectivities, a further complicating factor is that when the spoken language is the focus of classroom activity there are often other aims which the teacher 
might have: for instance, helping the students to gain awareness of or to practice some aspect of linguistic knowledge." It means the students should be prompted to do many oral practices. In classroom, a major part of the teachers' job is to expose students to language so that they can use it later. So the exposing students to speak can become the first to do, and how to do this needs proper consideration in choosing and using appropriate technique and media.

One of media that can be used to teach speaking is a series picture. Wright (2006) said that picture can be used in activities which offer little more than mechanical practice in the use of the language or may be used in communicative activities which would be meaningful to the students even if they did them in their own language.

So media picture can encourage the learners to learn more easily and communicatively also can create a sense of curiosity. The learners will be interested to do the activities and they have eager to develop their English especially in increasing their speaking. Series picture presents non-verbal (abstract) concept, visualization through series picture can help the students the meaning of words or difficult structure in a language and can increase a new vocabulary for the learners to speak.

According to Wright (2006:129), there were some advantages of using series picture. Pictures are able to motivate the students to speak or to write, they create a context which his/her response will have meaning, they also provides the student with information to use in controlled practice work, then pictures show objects, actions and events relationships can cue answers to questions, substitutions and sentence completions, and last they can sponsor, stimulate and possibly to guide, spoken and written descriptions, narrations or dialogues. Kreidler (1987:35) also put forward the advantages of series picture, he said that pictures can show relationship of many subjects to one another as well as performance of action, they can increase the students' motivation; arouse students' interest and attract attention, and they event can save the classroom time in keeping long explanation to a minimum.

So it can be concluded that media picture can encourage the learners to learn more easily and communicatively and also create a sense of curiosity. The learners will be interested to do the activities and they have eager to develop their English especially in increasing their speaking. Series picture presents non-verbal (abstract) concept, visualization through series picture can help the students the meaning of words or difficult structure in a language and increase a new vocabulary for the learners. The learners also are able to use their own word freely as long as it is still suitable with the picture theme.

\section{RESEARCH METHOD}

\section{Participants}

The participants for this study were 32 students of class $\mathrm{Xa}$ (12 males and 20 females) from a single class in MA AlHikmah Bandar Lampung. MA Al Hikmah Bandar Lampung is a formal school managed by KEMENAG. It equals with Senior High School (SMA). This education 
needs 3 years to graduation, from tenth until twelfth grade.

There were two classes in $\mathrm{X}$ grade in MA Al Hikmah Bandar Lampung, Xa and $\mathrm{Xb}$. The sample of research was $\mathrm{Xa}$ determined by using cluster random sampling technique. It was applied because the average score of tenth class was homogeneous.

\section{Design and Procedures}

In this research design, pre-experimental method was used. So the writer used this research method by involving himself in teaching learning process. The writer taught one class and gave pre-test and post-test to investigate the result of the research.

The research design of the study can be described as follow:

\begin{tabular}{llll}
$\mathrm{R}$ & 01 & $\mathrm{X}$ & 02 \\
\hline
\end{tabular}

In which,

R : Respondents

01 : pre-test

02 : post-test

$\mathrm{X}$ : treatment using series picture

technique

During the experiment, the class was taught speaking by using series picture. The students would be given pre-test to know the students' speaking ability before the experiment. After experiment, the post-test (same test with pre-test) were given to students to know how the influence of series picture for students' speaking ability. The study was carried out in four phases:

Phase one: Initial Planning
In this phase, a discussion between the researchers and the teacher teaching the students was carried out in the end of December 2010. The discussion was important in briefing and explaining to the teacher of the purposes, objectives, and procedures of the research as well as syllabus.

Phase two: Pre-test

Students were given the pre-test by teacher in January 2011 to know the students' speaking proficiency before the treatment. They were given 5 minutes to perform in front of classroom. The plot was meeting with a new student. They gave information of the location of some places in the school, namely: library, canteen, language laboratory, school field, toilet, parking area, administration room, and teachers' room.

Phase three: The treatment of using series picture.

The researcher makes the procedures of teaching speaking by using pictures as the media as follows: (a) Introducing the topic: The teacher announced what topic given to students for that day. The topic was chosen based on the book. The topic was about Descriptive Text. (b) Brainstorming: here the teacher begins instruction by having students brainstorm words related to the concept of Cinderella story. When they brainstorm, make them list words on their worksheet and make sure the target words are included. (c) Explaining the concept of the series picture: the teacher started explaining the definition of series picture. 
Here, one series picture would be shown as an example then the teacher taught how to describe it. (d) Giving the students question: to know whether the students had understood or not of the story, the teacher gave some questions. It could be W-H questions (What, where, when, why, who and How). (e) Performing: The teacher lets the students stand up in front of class and use their own language to describe spontaneously and freely based the series picture. The focus is on meaning, not grammar or vocabulary (what to say is much more important than how to say).

Phase four: post-test

The students underwent a post-test given by the teacher in March 2011. As in the pre-test, the students gave information about the location of some places in the school. They were given 5 minutes to perform in front of the class.

\section{The Analyzing of data}

The result of test was analyzed by t-test formula to make sure whether there was a significant difference between pre-test and post-test. The formula is as follow:

$$
t_{0}=\frac{M_{1}-M_{2}}{S E_{M_{1}-M_{2}}}
$$

Notes:

$\mathrm{t}_{0} \quad$ : Test of " $\mathrm{t}$ "

M1 : Mean variable 1

M2 : Mean variable 2

$S E_{M_{1}-M_{2}}$ : Standard error of the different mean between variable I and Variable II.

\section{FINDING}

The findings of the study indicated that Series Picture technique was successful in improving the students' speaking ability as well as increasing their involvement in the teaching and learning activities. It can be seen from the students' average score in post - test is 70.36 and the students' average score in pre - test is 64.05. Besides, the finding indicated that Series pictures technique was effective in enhancing the students' involvement in the speaking activities.

Furthermore, the findings also revealed that the appropriate model of Series Picture technique in teaching speaking consisted of the following steps: (1) brainstorming by singing and giving questions to students related to what will be done, (2) telling students what is going to be done, (3) dividing students into groups; each group sits in circle, (4) giving different incomplete picture series to each group, (5) assigning students to tell their teammates about the pictures in turns; students may make note before sharing what they see in the pictures, (6) telling students to gather all information they get from other teammates; students may write the information (7) telling students to conclude the end of the story after they have already got all the information from the teammates, (8) telling students that the end of the story is free based on their imagination (9) assigning students to perform the story in front of the class individually one by one.

With the findings, it can be inferred that Series Picture technique has been proven to improve not only the students' speaking ability but also the students' involvement in the learning process, particularly in the speaking activities. 
Therefore, it is suggested that English teachers apply this technique as one of the alternatives that can be used in teaching speaking skill. Besides, it is also suggested to future researcher conduct a similar study by using Series Picture technique on different settings and subjects to see whether or not this technique is also effective and applicable to be implemented in improving the students' speaking ability. It can also be for another productive skill like writing. Since it is beneficial not only in improving the students' speaking ability but also the students' involvement in the learning process, it is advisable that this technique be used by students as their learning strategy to practice their speaking ability, and even more to practice their writing skill as well. This activity can be done in their extra curricular activities.

\section{DISCUSSION}

In this research, there were many students got difficulties in speaking because they could not develop their ideas in spoken form well. Obviously, teachers of English have to be creative in teaching speaking to avoid monotonous and boring activities. One of technique that can be used is using series picture. It is found that series pictures can help the students to improve their speaking ability

The writer can prove the hypothesis that series picture has positive influence in implementing it in the classroom, because after the writer conducted this research, the fact the students' score of post -test is higher than pre - test score. It was caused because series pictures could help students to develop their ideas to speak well and the most important was the students got fun in learning teaching process. Based on the data analysis, it has got $t_{0}=3.45$. So it means that the influence of using series picture towards students' speaking ability is positive.

The pedagogical implication of this study is focused on improving the quality of the teaching and learning process in Indonesia especially the teaching of speaking skill. The finding of this research may help students improve their English competence in speaking ability. It is suggested that teachers are able to use series picture as one of alternatives in teaching speaking media. Besides, to make students are challenged and triggered to speak, it is expected that teacher choose appropriate and interesting topic for the students. Looking at the limitations mention above, it is also expected for further studies to conduct the research to solve the limitation in this study.

\section{CONCLUSION}

Based on the result of the research, the writer would like to make some conclusion as follows:

1. Teaching speaking through series picture gives positive influence to increase the students' speaking ability. Based on the data analysis, it has got $\mathrm{t}_{0}$ $=3.45$. So it means that the implementation of using series picture towards students' speaking ability is positive.

2. Teaching speaking through series picture is more effective. It can be seen 
from the students' average score in post - test is 70.36 and the students' average score in pre - test 64.05

\section{REFERENCES}

Andrzejczak, N. (2005). From image to text: Using images in the writing process. International journal of education \& the arts.

Anonim, Departemen Pendidikan Nasional. Kurikulum Bahasa Inggris 2004.

Brown, H. D.(2001). Teaching by principles. An interactive approach to language pedagogy, second edition. New York: Longman Inc.

Chunpan, Y. (2009). The effects of pictures on the reading comprehension of low-proficiency Taiwanese English foreign language college students: An action research study. VNUJournal of Science, Foreign Languages 25.

Gutierrez, K. G, Puello \& Galviz. (2015). Using pictures series technique to enhance narrative writing among ninth grade students at Institución Educativa Simón Araujo. English language teaching; Vol. 8, No. 5.

Harmer, J. (2001). The practice of English language teaching (3rded.). London: Longman.

Hornby.1987. Audio material visual. New York: Harper and Brother.

Hughes, Rebecca.(2002). Teaching and researching speaking. London: Longman.
Hutchinson, T., \& Waters, A. (1987). English for specific purposes. New York: Cambridge University Press.

Kreidler, Lois J, Carmol.(1987). Visual aid for teaching English of other language. Washington DC: United States Information in Agancy.

Mardiana, Afriyani, Latifah \& Hotimah.(2015). The Low Motivation of Students in Learning English Foreign Language in The Context Of Speaking. Sultan Ageng Tirtayasa University. Retrieved October 13, 2015 from https:/www.academia. edu/4766541.

Nunan, David.(1991). Practical English Language Teaching. Intemational Edition.

Nurhayati. (2014). Using Picture Series to Inspire Reading Comprehension for The Second Semester Students of English Department of Iain Tulungagung. Dinamika Ilmu. Vol. 14. № 2.

Rosmawati. (2013). Enhancing the L1 Primary Students' Achievement in Writing Paragraph by Using Pictures. International Journal of Education \&Literacy Studies. Vol. 1 No. 2.

Wright, Andrew.(2006). 1000 Pictures for teachers to Copy. RevisedEdition.Longman.

Zacharias, N.T. (2003). A survey of tertiary teachers' beliefs about English Language Teaching in Indonesia with regard to the role of English as a global language. MA-ELT THESIS.Institute for English Language Education Assumption University of Thailand. 